\section{A retrospective analysis of emergency department usage in rural and semi-urban indige- nous Guatemalan populations}

\author{
Emma L. Svenson, ${ }^{1}$ Amber Sheth, ${ }^{1}$ \\ Jessica Schmidt, ${ }^{2}$ Rafael Tun, ${ }^{3}$ \\ James E. Svenson ${ }^{2}$ \\ ${ }^{1}$ University of Wisconsin-Madison \\ School of Medicine and Public Health, \\ Madison, Wisconsin; ${ }^{2}$ Department of \\ Emergency Medicine, University of \\ Wisconsin-Madison School of Medicine \\ and Public Health, Madison, Wisconsin, \\ USA; ${ }^{3}$ Hospital Parroquial de San Lucas \\ Tolimán, San Lucas Tolimán, Guatemala
}

\section{Abstract}

Functioning healthcare systems provide emergency medical care. Disparities exist in accessibility and availability of emergency care in low- and middle-income countries. We present a descriptive epidemiologic analysis of Emergency Department (ED) usage in a rural, indigenous Guatemalan population. San Lucas Tolimán is situated in central Guatemala. Hospital Parroquial de San Lucas offers emergency care to San Lucas Tolimán and surrounding villages. All ED visits between January 1 ${ }^{\text {st }}, 2016$ and December 31st 2018 were recorded and analyzed. During the study period, 12,229 patient encounters occurred. Almost all patients identified as indigenous. Children comprised $43 \%$ of visits. Medical issues represented a majority $(83 \%)$ of complaints. Respiratory (40\%) and gastrointestinal disease $(26 \%)$ were frequent presenting complaints. Almost all visits (83\%) occurred during the day and evening hours. Trauma/surgical complaints were slightly more frequent at night. $93 \%$ of patients were discharged, while the rest were admitted or transferred. These data contribute to understanding of disease burden and emergency care needs and capacity in rural areas of low- and middle-income countries. This information may be used to inform local policy decisions, identify research priorities, and create training topics for local health care providers in Guatemala and other countries in this region.

\section{Introduction}

The provision of emergency medical care is a crucial component of successful healthcare systems. ${ }^{1}$ Emergency care is a primary response to time-sensitive medical conditions such as trauma, obstetric complications, or ischemic cardiovascular disease, and prevents significant morbidity and mortality associated with these acute conditions. Emergency care also represents an entry point for access to additional specialized care, providing crucial preventive health services at a population level. ${ }^{2-4}$ In nations where a significant portion of people are uninsured or underinsured, and lack access to primary care providers, emergency departments are even becoming point of care for non-urgent medical conditions. , $^{5,6}$ A lack of emergency care infrastructure is thus linked to poorer health outcomes, and ensuring access to emergency medical care is being prioritized as a mechanism to improve overall population health on a global scale. $1,3,4,7$

While emergency medical systems are often robust in high-income countries, significant obstacles exist to developing, delivering and accessing emergency care in lowand middle-income countries. ${ }^{89}$ Lack of transportation to medical facilities, affordability of services, poor facility infrastructure, decreased availability of medical supplies and medications, and a paucity of skilled emergency providers and emergency training programs are all frequently cited barriers to providing effective acute care in these settings. ${ }^{2,10-15}$ Yet Lower- and MiddleIncome Countries (LMIC) frequently shoulder a significant burden of critical acute illness. ${ }^{13}$ For example, recent estimates suggest that ninety percent of trauma related deaths occur in LMIC. ${ }^{13,16}$ In addition to the burden of infectious diseases, the acute health sequelae associated with non-communicable diseases, including diabetes and heart disease, are also on the rise in these areas. ${ }^{2,13,17-20}$ Based on the rising burden of acute illness in LMIC, there is a growing impetus to understand emergency care needs and strengthen capacity. ${ }^{20-25}$

Little is known about access to, and availability of, emergency care in Central and South America. ${ }^{9}, 11$ Guatemala is the most populous nation in Central America. Since 1999, the Guatemalan Ministry of Health has undertaken initiatives to develop pre-hospital and in-hospital emergency care, and advanced disaster preparedness on a national level. ${ }^{12}$ However, hospital emergency departments are typically staffed by rotating physicians and medical students without formal emergency medical training. It is only recently that international partnerships have led to the establishment of Guatemala's sole emergency medicine residency at the Universidad de San Carlos de Guatemala, with the first matriculated class of residents entering the program in
Correspondence: Emma L. Svenson, University of Wisconsin-Madison School of Medicine and Public Health, Madison, Wisconsin.

Tel: 608.216 .5396

E-mail: svenson@wisc.edu

Key words: Acute care; underserved populations; Guatemala.

Contributions: ELS: Study design, data analysis, and original write-up of manuscript; AS: Study design, data collection, editing manuscript; JS: Study design, editing manuscript; RT: Role: Study design, data collection, editing manuscript; JES: Study design, data analysis, editing manuscript

Conflict of interest: The authors have no conflict of interest to declare.

Conference presentation: Svenson EL, Sheth AM, Schmidt JN, Tun R, Svenson JE. A retrospective analysis of emergency department usage in rural and semi-urban indigenous Guatemalan populations. Poster presentation. International Conference of Emergency Medicine (virtual). Abu Dhabi, June 2021

Availability of data and materials: All data generated or analyzed during this study are included in this published article.

Ethics approval and consent to participate: The Institutional Review Board of the University of Wisconsin-Madison determined this study to be exempt, and this study was also reviewed and approved by the medical board of the Friends of San Lucas mission. The study is conformed with the Helsinki Declaration of 1964, as revised in 2013, concerning human and animal rights.

Received for publication: 29 December 2021. Accepted for publication: 13 January 2022.

This work is licensed under a Creative Commons Attribution 4.0 License (by-nc 4.0).

(C) Copyright: the Author(s), 2022

Licensee PAGEPress, Italy

Healthcare in Low-resource Settings 2022; 10:10256 doi:10.4081/hls.2022.10256

2019. ${ }^{12,26,27}$ Although there is increasing access to emergency medical care in urban areas, provision of emergency services to rural areas is not widespread. ${ }^{12}$ Strikingly, up to fifty-five percent of Guatemala's population inhabit geographically isolated rural regions, the majority of which is indigenous Mayan. ${ }^{28}$

Indigenous populations often face unique challenges to accessing emergency medical care. ${ }^{28-34}$ Although Guatemala ranks as a middle-income country based on Gross Domestic Product (GDP), extreme 
income inequality endures, with $79 \%$ of Guatemala's indigenous population living in poverty. ${ }^{28,35}$ Routine preventive care and medications can be obtained free of charge at government run health centers (centros de salud) throughout Guatemala; however, poor staffing, long wait-times and lack of medical supplies at these free, governmentsponsored public hospitals drives rural residents to seek care both routine and emergency care at private hospitals, where the high out-of-pocket cost of medical care can act as a deterrent to seeking treatment. Furthermore, widespread discrimination at biomedical institutions, including both physical and mental abuse, remains a common experience for indigenous patients. ${ }^{28,36-}$ 40 These barriers can be compounded by different cultural understanding of what constitutes a medical emergency, particularly in the case of obstetric emergencies. ${ }^{41-43}$

To our knowledge, there have been limited studies examining emergency medical services in Guatemala, with few specifically examining acute care needs and emergency medical service utilization in rural and semi-urban indigenous populations. The scope of these articles is narrowly focused on emergency training program development, pre-hospital care, and pediatric case management. ${ }^{12,44-47}$ Therefore, the goal of this study is to provide a basic descriptive analysis of an Emergency Department (ED) located in rural Guatemala, to better define acute disease burden and emergency care needs in a representative rural Guatemalan community.

\section{Materials and Methods}

San Lucas Tolimán is located on the Southeast shores of Lake Atitlán and is considered part of the Guatemalan highlands. San Lucas Tolimán is home to a population of 17,000 people living in a semi-urban central village, with an additional 14,000 people living in 19 surrounding rural communities. A majority of its population identifies as indigenous Mayan. ${ }^{48,49}$ The impact of recent civil war and genocide is substantial and persistent in these mountain communities, with substantial cultural and socioeconomic barriers limiting access to education, basic sanitation, and healthcare. ${ }^{50,51}$ The average yearly income in the San Lucas Tolimán area is less than 1,000 U.S. dollars (USD), or the equivalent of $\$ 3$ USD per day. ${ }^{49,52,53}$

Multiple healthcare practices are present in the San Lucas area. For example, government run health centers (centros de salud) provide free primary care services to San Lucas and surrounding communities.
Residents have identified poor staffing and supply shortages as deterrents to seeking care at these institutions. ${ }^{52}$ An IGSS (Instituto Guatemalteco de Seguridad Social) is located in the town proper, and also provides free, routine health services to certain patients and employers who pay into the IGSS system. As of 1995, only $16 \%$ of Guatemala's total population was covered through the IGSS, indicating that this service is not accessible to many Guatemalans. ${ }^{54-57}$ Several private clinics are also present in the town proper. ${ }^{53}$ Emergency care is available to residents of San Lucas Tolimán at hospitals in neighboring municipalities, such as the Hospitalito Atitlán or Hospital Nacional de Sololá. Emergency care is also available closer to home at the Hospital Parroquial de San Lucas Tolimán (Hospital Monseñor Gregorio Schaffer), and this hospital is the focus of this study. ${ }^{35,58}$

A nonprofit organization, The Friends of San Lucas, in association with the San Lucas Mission, provides social services based on community needs, and helped establish a low-cost private hospital in San Lucas Tolimán in the late 1990's, Hospital Parroquial de San Lucas Tolimán (Hospital Monseñor Gregorio Schaffer). This hospital regularly employs one physician (on call 24 hours/day), along with several nurse practitioners, who help staff the emergency department after normal business hours. The hospital partners with an established health promoter program and volunteer international healthcare providers to offer basic medical care and health education onsite to neighboring communities and within San Lucas's town proper. The hospital also coordinates with internationally based physicians to offer advanced surgical, ophthalmologic, and dental care, among other specialties. A daily clinic is offered on a first come-first serve basis by the hospital's regularly employed physician. Emergency care is also available twenty-four hours a day at the hospital, a fact that is well-known in the community, and that is advertised on the hospital's website and social media sites, among other media sources. The emergency department includes an ambulance available for emergency transport. Referrals to other hospitals are made as necessary. ${ }^{48,49,59-61}$

Over a three-year period between January $1^{\text {st }}, 2016$ and December $31^{\text {st }}, 2018$, all ED visits to Hospital Parroquial de San Lucas Tolimán were collected and entered into an Excel database by hospital staff at time of visit. The information gathered for each patient encounter included age, gender, whether or not an individual was indigenous, municipality/department/coun- try of origin, date and time of service, chief complaint, category of chief complaint, if medical or surgical treatments were recommended, and if follow-up care was required. Categories of chief complaint were designated by hospital staff included abdominal, auditory, cardiovascular, dermatologic, diarrheal/parasitic, gynecologic, hematologic, infectious, neurologic, nutritional, ophthalmologic, dental, post-operation, surgical, renal/urinary, respiratory, rheumatic/ endocrine, traumatic, premature, not diagnosed, or other.

All analyses were performed using SAS v 9.4 (SAS Corporation, Cary, NC). Groups were compared using student's t-test for continuous variables, or with Fisher's exact or Mantel Haenzel Chi Square test for categorical variables. Variations between multiple variables were carried out with logistic regression for dichotomous variables, or generalized linear models for categorical variables with multiple outcomes.

This study was determined to be exempt by the Institutional Review Board at the University of Wisconsin-Madison, as defined by the Federal Regulations for Protection of Human Research Subjects. This study was also reviewed and approved by the medical board of the Friends of San Lucas mission prior to accessing and analyzing data, which includes both local hospital staff and international partners. It was conducted with the full support of the Hospital Parroquial de San Lucas Tolimán, the Friends of San Lucas, and the San Lucas Mission.

\section{Results}

\section{Demographic information}

Between January $1^{\text {st }} 2016$ and December $31^{\text {st }} 2018$, a total of 12,229 patient encounters were recorded, 46.15 $(\mathrm{N}=5644)$ male and 53.85\% $(\mathrm{N}=6585)$ female. The average age was $24.0 \pm 23.8$ years for males and $29.0 \pm 24.0$ years for females $(p<0.01)$. The age distributions of patients presenting to the ED were similar for both sexes as shown below in Figure 1, although a slightly greater proportion of patients were male in each age category below 18 years, whereas a greater proportion of patients were female in each age category over 18 years.

Children $<18$ years old represented $43 \%$ of all patient visits to the ED, shown in Figure 2.

Almost all patients presenting to the ED were indigenous $(92.1 \%, \quad \mathrm{~N}=11248)$. Female patients comprised the bulk of both indigenous and non-indigenous patient vis- 
its to the $\mathrm{ED}, 53.23 \%$ and $61.06 \%$ respectively. Non-indigenous patients tended to be older, with an average age of $34.61 \pm 26.18$ compared to $26.0 \pm 23.71(\mathrm{p}=0.001)$.

\section{Patient origin}

Guatemala is divided into 22 departments, and further subdivided into 331 administrative districts called municipalities..$^{51,62}$ During the time period of our study, almost all patients presenting to the ED reported primary residence in Sololá $(\mathrm{N}=11,430,93.5 \%)$, the department in which Hospital Parroquial de San Lucas Tolimán is located. The remaining patients were from 14 other departments scattered throughout Guatemala, $6.06 \%(\mathrm{~N}=741)$, or from foreign countries, $0.46 \% \quad(\mathrm{~N}=58)$. Guatemalan departments represented at the ED included Alta Verapaz, Jutiapa, Petén, Retalhuleu, Totonicapán, Suchitepéquez, Santa Rosa, San Marcos, Quiche, Quetzaltenango, Huehuetenango, Escuintla, Chimaltenango and La Ciudad de Guatemala. Patients from foreign countries included residents of England, Germany, Belize, El Salvador, Spain and the United States.

The department of Sololá was examined at a more granular level. Within this department, the municipality of San Lucas Tolimán was the primary residence for most patients presenting to the ED, 90.09\% ( $\mathrm{N}=9803)$. Nine other municipalities in Sololá were represented, although a bulk of patients came from municipalities bordering San Lucas Tolimán, including San Antonio Palopó (5.11\%, N=556) and Santiago Atitlán
(4.34\%, N=472). As mentioned previously, the municipality of San Lucas Tolimán includes the semi-urban town of San Lucas Tolimán, with numerous rural communities surrounding the town proper. Of the 9,803 residents residing in San Lucas Tolimán, $88.92 \%(\mathrm{~N}=8,717)$ lived in the town proper, and $11.08 \%(\mathrm{~N}=1,086)$ lived in surrounding rural communities.

\section{Temporal and seasonal variability}

Over a three-year span, a slight increasing trend in annual presentations was observed. Of the 12,229 total patient encounters recorded, $29.98 \%(\mathrm{~N}=3,666)$ occurred in 2016, 32.43\% $(\mathrm{N}=3,966)$ occurred in 2017 , and $37.59 \%(\mathrm{~N}=4,597)$ occurred in 2018. This trend was significant $(p<0.001)$. In Guatemala, the rainy season lasts from May through October, while the dry season lasts from November to April. A total of 6,070 patient encounters $(49.64 \%)$ occurred during the rainy season. A total of 6,159 patient encounters $(50.36 \%)$ occurred during the dry season. There was no statistically significant change in number of ED visits across seasons $(p=0.42)$. Visits were also evenly distributed across individual months, shown in Figure 3.

The bulk of ED visits $(\mathrm{N}=10,453$, $85.3 \%$ ) occurred during the day (7 am -3 pm) and evening ( 3 pm - 11 pm) hours. Relatively fewer visits occurred during night hours from $11 \mathrm{pm}-7$ am $(\mathrm{N}=1,796$, $14.69 \%)$. This trend was significant ( $\mathrm{p}$ $<0.0001)$.

\section{Chief complaint and disposition}

Presenting complaint was recorded for all patients, and these were categorized into one of 21 categories by the hospital. These were further stratified as medical or surgical complaints. Medical complaints accounted for most of the visits to the ED (83.1\%). There was a statistically significant difference in the proportion of males presenting with a surgical complaint (12.59\%) compared to females $(21.90 \%)$. A slight temporal variability was also observed, with a greater proportion of surgical complaints occurring during day and evening hours (19.50\% and $16.73 \%$ respectively). Within the municipality of San Lucas Tolimán, rural residents presented more frequently with surgical complaints $(19.98 \%)$ than did their semi-urban counterparts (16.28\%). Type of complaint did not appear to be significantly correlated with season, ethnicity or outcome. These results are shown in Table 1. Overall, a majority of patients were discharged to home from the ED 93.02\% $(\mathrm{N}=11,298) .814$ patients $(6.7 \%)$ were either admitted to the hospital or referred to another hospital for care, such as the Hospital Universidad del Valle de Guatemala or the Hospital Nacional de Sololá. Thirty patients, $0.25 \%$, did not survive to discharge.

Medical visits were categorized into respiratory illnesses, Cardiovascular Disease (CV), Gastrointestinal (GI) disease, neurological disease (neuro), and other. The majority of these medical visits were either respiratory $(\mathrm{N}=4,110,40.4 \%)$ or GI

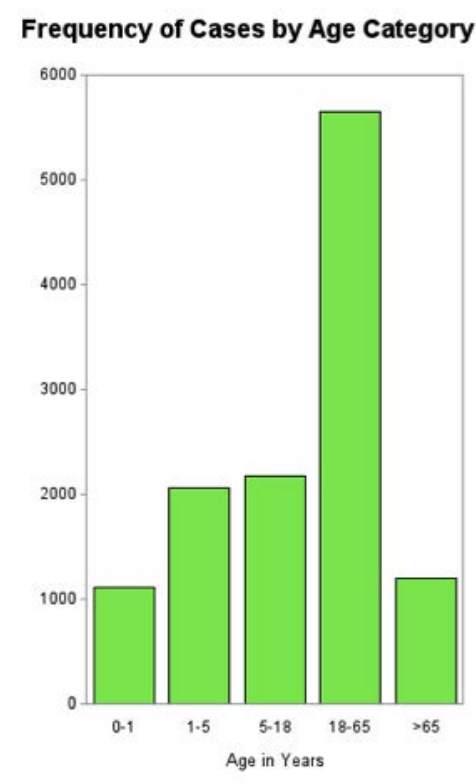

Figure 2. Age distribution of all patients presenting to the $\mathrm{ED}$ over a three-year period by age group $<1,1-5,5-18,18-65$ and $>65$ years old.

Figure 1. Distribution of patient age based on sex over a three-year period. 
$(\mathrm{N}=2694,26.5 \%)$. While the pattern of medical complaints was similar between indigenous and non-indigenous patients, indigenous patients presented more frequently with respiratory complaints and non-indigenous patients present more frequently with cardiovascular issues. During the dry season, presentation for GI complaints was slightly more common, but there was no significant difference in complaint distribution between the two seasons. These results are shown in Table 2 .

Presenting complaint for medical cases varied significantly by age (Figure 4). While respiratory complaints were the most frequent in most age groups, for adults aged 18-65 years, GI complaints were the most frequent complaint. For older adults $>65$ years, cardiovascular problems were almost as common as respiratory complaints.

Traumatic complaints made up 43.2\% of all surgical presentations to the ED. The average age of patients presenting with trauma was 31.9 years. Most trauma cases occurred during day or evening hours, and only $39.33 \%$ of surgical cases presenting to the ED during late-night hours were traumas. There were no significant seasonal trends in the distribution of surgical complaints. Female patients presented more frequently with trauma compared to male patients. In general, a greater proportion of trauma cases were admitted to the hospital or referred to another institution for follow up care $(54.48 \%)$, compared to other surgical complaints. These results are shown in Table 3. A greater proportion of patients presenting to the ED with a traumatic surgical complaint were referred (8\%) compared to admitted $(1.03 \%)$, whereas an equal proportion of patients presenting to the ED with nontraumatic surgical complaints were

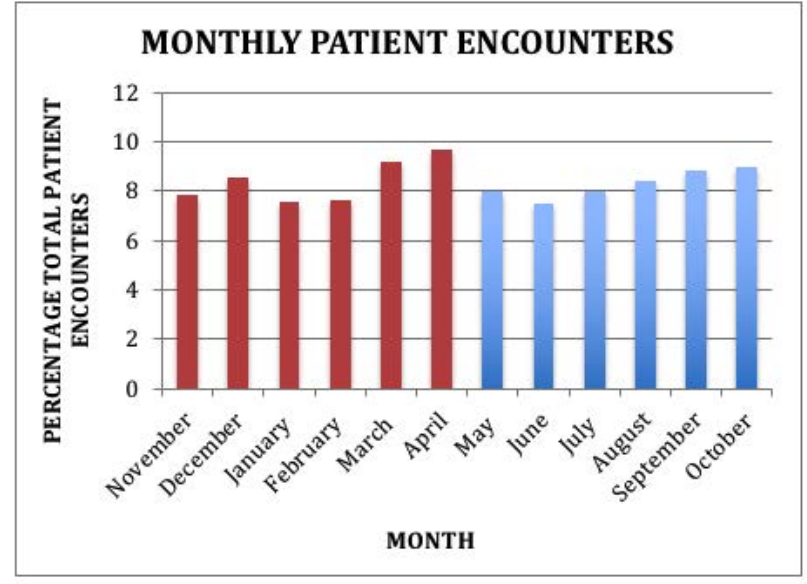

Figure 3. Distribution of monthly patient encounters from January $1^{\text {st }}, 2016$ to December $31^{\text {st }}$, 2018. Rainy season is depicted in blue, and dry season is depicted in red.

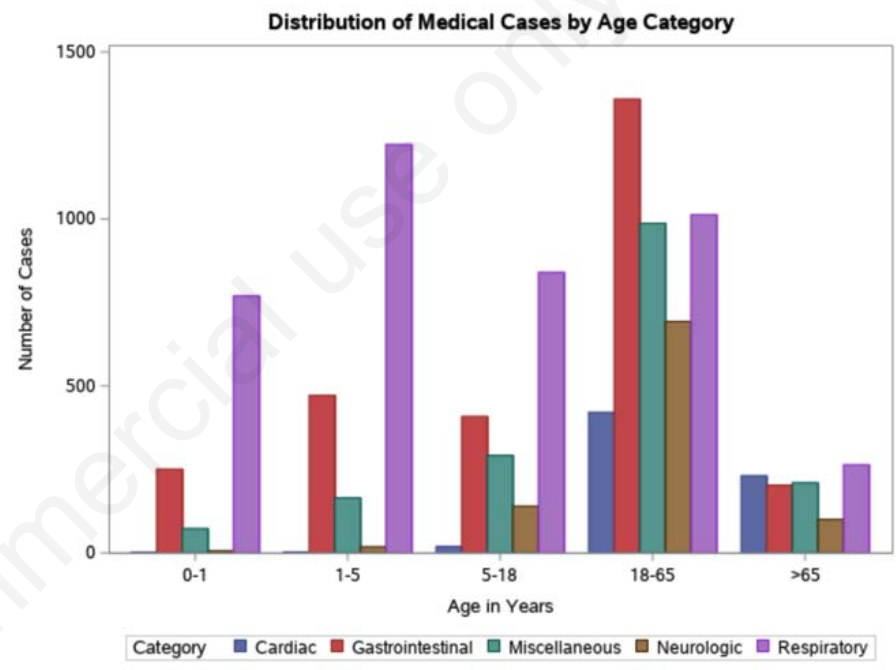

Figure 4. Frequency of medical complaints across age categories, $<1,1-5,5-18,18-65$, and $>65$ years old.

Table 1. Demographic characteristics, seasonal/ temporal characteristics, and disposition associated with patients presenting for medical or surgical complaints over a three-year period.

\begin{tabular}{|c|c|c|c|c|}
\hline & & Medical complaint $(\%, N=10,164)$ & Surgical complaint $(\%, \mathrm{~N}=2,065)$ & $p^{*}$ \\
\hline Average age (years) & & 25.9 & 30.28 & $<0.0001$ \\
\hline Location & $\begin{array}{l}\text { Rural } \\
\text { Semi-urban }\end{array}$ & $\begin{array}{l}80.02 \\
83.72\end{array}$ & $\begin{array}{l}19.98 \\
16.28 \\
\end{array}$ & 0.001 \\
\hline Season & $\begin{array}{l}\text { Rainy } \\
\text { Dry }\end{array}$ & $\begin{array}{l}83.05 \\
83.18\end{array}$ & $\begin{array}{l}16.95 \\
16.82\end{array}$ & 0.4914 \\
\hline Time & $\begin{array}{l}7 \mathrm{am}-3 \mathrm{pm} \\
3 \mathrm{pm}-11 \mathrm{pm} \\
11 \mathrm{pm}-7 \mathrm{am}\end{array}$ & $\begin{array}{l}80.50 \\
83.27 \\
90.09\end{array}$ & $\begin{array}{c}19.50 \\
16.73 \\
9.91\end{array}$ & $<0.0001$ \\
\hline Indigenous & $\begin{array}{l}\text { Yes } \\
\text { No }\end{array}$ & $\begin{array}{l}83.21 \\
82.04\end{array}$ & $\begin{array}{l}16.79 \\
17.96\end{array}$ & 0.5743 \\
\hline Sex & $\begin{array}{l}\text { Male } \\
\text { Female }\end{array}$ & $\begin{array}{l}78.10 \\
87.41\end{array}$ & $\begin{array}{l}21.90 \\
12.59\end{array}$ & $<0.0001$ \\
\hline Outcome & $\begin{array}{l}\text { Discharge } \\
\text { Admit/ refer }\end{array}$ & $\begin{array}{l}83.31 \\
82.19\end{array}$ & $\begin{array}{l}16.69 \\
17.81\end{array}$ & 0.4248 \\
\hline
\end{tabular}

* p-value of regression model containing all variables. 
referred $(2.84 \%)$ compared to admitted $(2.84 \%)$.

\section{Discussion}

Emergency medical care has a demonstrable impact on healthcare system functions, yet scant data exist to describe emergency department availability, access and utilization in low- and middle-income countries. ${ }^{9,20,63}$ Data from South and Central America are especially scarce.,9,11,63 This study represents the first attempt to describe the functioning of an emergency department in a rural and semi-urban setting in Guatemala. Although a vast majority of emergency departments worldwide still rely on paper-based records, electronic documentation of patient presentation to
Hospital Parroquial de San Lucas Tolimán allowed for nearly full capture of acute care during the time period studied. ${ }^{64}$

While presentations to the ED were fairly consistent between months and seasons, time of patient presentation over the course of a day followed a clear distribution. A majority of patient encounters occurred during day and evening hours (7 am $-11 \mathrm{pm})$. Relatively fewer patients presented to the ED during late evening or early morning hours (11 pm - $7 \mathrm{am})$. This finding is consistent with other studies of emergency department utilization in LMIC. ${ }^{65-67}$ For example, a tertiary care institution in Northern India found that peak patient encounters occurred during day and evening hours and concluded that a lack of readily available transportation may be responsible for this temporal distribution, given that an ambulance was not available, public transportation shuts down at 21:00, and personal vehicles are difficult to arrange. ${ }^{66}$ Another study of trauma systems in Kenya also found that transportation at night was a barrier to accessing care, given the risk of being hijacked or shot. ${ }^{67}$ In remote rural areas of Guatemala, many families live without access to motor vehicles, and there is poor public transportation infrastructure. ${ }^{68}$ For people living in mountain hamlets and rural areas, traversing roads on foot may take several hours, and may be impassable depending on weather conditions, or generally unsafe at night. ${ }^{69}$ Thus, the temporal distribution of patient presentation at this hospital underscores that transportation, distance and road infrastructure may still be significant barriers to accessing acute care in the predominantly indigenous

Table 2. Demographic characteristics, seasonal/ temporal characteristics, and disposition associated with patients presenting for medical complaints over a three-year period.

\begin{tabular}{|c|c|c|c|c|c|c|c|}
\hline & $\begin{array}{r}\mathrm{Re} \\
(\%\end{array}$ & $\begin{array}{l}\text { spiratory } \\
N=4,110)\end{array}$ & $\begin{array}{c}\text { Cardiovascular } \\
(\%, N=676)\end{array}$ & $\begin{array}{c}\text { Gastrointestinal } \\
(\%, N=2,694)\end{array}$ & $\begin{array}{c}\text { Neurological } \\
(\%, N=957)\end{array}$ & $\begin{array}{c}\text { Other } \\
(\%, N=1,727)\end{array}$ & $\mathbf{p}^{*}$ \\
\hline Average age (years) & & 55.2 & 25.9 & 35.9 & 32.4 & 16.0 & $<0.0001$ \\
\hline Location & $\begin{array}{l}\text { Rural } \\
\text { Semi-urban }\end{array}$ & $\begin{array}{l}33.26 \\
42.89\end{array}$ & $\begin{array}{l}4.14 \\
7.07\end{array}$ & $\begin{array}{l}30.49 \\
25.61\end{array}$ & $\begin{array}{l}11.85 \\
8.77\end{array}$ & $\begin{array}{l}20.25 \\
15.66\end{array}$ & 0.0001 \\
\hline Season & $\begin{array}{l}\text { Rainy } \\
\text { Dry }\end{array}$ & $\begin{array}{l}40.71 \\
40.17\end{array}$ & $\begin{array}{l}6.41 \\
6.89\end{array}$ & $\begin{array}{l}25.03 \\
27.95\end{array}$ & $\begin{array}{l}9.92 \\
8.92\end{array}$ & $\begin{array}{l}17.93 \\
16.06\end{array}$ & 0.4797 \\
\hline Time & $\begin{array}{l}7 \mathrm{am}-3 \mathrm{pm} \\
3 \mathrm{pm}-11 \mathrm{pm} \\
11 \mathrm{pm}-7 \mathrm{am}\end{array}$ & $\begin{array}{l}39.94 \\
41.58 \\
38.57\end{array}$ & $\begin{array}{l}5.86 \\
7.58 \\
6.12\end{array}$ & $\begin{array}{l}25.70 \\
24.79 \\
33.25\end{array}$ & $\begin{array}{c}8.84 \\
10.02 \\
9.21\end{array}$ & $\begin{array}{l}19.66 \\
16.03 \\
12.86\end{array}$ & $<0.0001$ \\
\hline Indigenous & $\begin{array}{l}\text { Yes } \\
\text { No }\end{array}$ & $\begin{array}{l}41.18 \\
31.52\end{array}$ & $\begin{array}{c}6.06 \\
13.54\end{array}$ & $\begin{array}{l}26.48 \\
26.84\end{array}$ & $\begin{array}{l}9.53 \\
8.23\end{array}$ & $\begin{array}{l}16.75 \\
19.87\end{array}$ & $<0.0001$ \\
\hline Sex & $\begin{array}{l}\text { Male } \\
\text { Female }\end{array}$ & $\begin{array}{l}44.90 \\
37.02\end{array}$ & $\begin{array}{l}5.24 \\
7.73\end{array}$ & $\begin{array}{l}25.25 \\
27.47\end{array}$ & $\begin{array}{c}6.74 \\
11.47\end{array}$ & $\begin{array}{l}17.88 \\
16.31\end{array}$ & $<0.0001$ \\
\hline Outcome & $\begin{array}{l}\text { Discharge } \\
\text { Admit/refer }\end{array}$ & $\begin{array}{l}41.25 \\
31.24\end{array}$ & $\begin{array}{l}6.65 \\
5.23\end{array}$ & $\begin{array}{l}25.86 \\
33.93\end{array}$ & $\begin{array}{l}9.75 \\
4.78\end{array}$ & $\begin{array}{l}16.49 \\
24.81\end{array}$ & 0.6091 \\
\hline
\end{tabular}

* p-value of regression model containing all variables

Table 3. Demographic characteristics, seasonal/ temporal characteristics, and disposition associated with patients presenting for surgical complaints over a three-year period.

\begin{tabular}{|c|c|c|c|c|}
\hline & & Trauma $(\%, N=892)$ & Other $(\%, N=1,173)$ & $\mathrm{p}^{*}$ \\
\hline Average age (years) & & 31.9 & 29.0 & \\
\hline Location & $\begin{array}{l}\text { Rural } \\
\text { Semi-urban }\end{array}$ & $\begin{array}{c}43.78 \\
42 \\
\end{array}$ & $\begin{array}{c}56.22 \\
58\end{array}$ & 0.6025 \\
\hline Season & $\begin{array}{l}\text { Rainy } \\
\text { Dry }\end{array}$ & $\begin{array}{l}41.21 \\
45.17\end{array}$ & $\begin{array}{l}58.79 \\
54.83\end{array}$ & 0.227 \\
\hline Time & $\begin{array}{l}7 \mathrm{am}-3 \mathrm{pm} \\
3 \mathrm{pm}-11 \mathrm{pm} \\
11 \mathrm{pm}-7 \mathrm{am}\end{array}$ & $\begin{array}{l}45.84 \\
41.01 \\
39.33 \\
\end{array}$ & $\begin{array}{l}54.16 \\
58.99 \\
60.67 \\
\end{array}$ & $\begin{array}{l}0.2761 \\
0.5640\end{array}$ \\
\hline Indigenous & $\begin{array}{l}\text { Yes } \\
\text { No }\end{array}$ & $\begin{array}{l}42.20 \\
52.60\end{array}$ & $\begin{array}{l}57.60 \\
47.40\end{array}$ & 0.0566 \\
\hline Sex & $\begin{array}{l}\text { Male } \\
\text { Female }\end{array}$ & $\begin{array}{l}39.97 \\
51.99 \\
\end{array}$ & $\begin{array}{l}60.03 \\
48.01 \\
\end{array}$ & 0.010 \\
\hline Outcome & $\begin{array}{l}\text { Discharge } \\
\text { Admit/ refer }\end{array}$ & $\begin{array}{l}41.99 \\
54.48 \\
\end{array}$ & $\begin{array}{l}58.01 \\
45.52 \\
\end{array}$ & 0.0005 \\
\hline
\end{tabular}

\footnotetext{
* p-value of regression model containing all variables.
} 
population studied. Interestingly, children and adolescents represented nearly half of all ED visits (43.2\%). Elderly patients over 65 years old were seen less frequently. Presumably younger patients are free of the chronic conditions that typically burden the increasing volume of elderly patients seen in high-income country emergency departments. ${ }^{9}$ However, other studies have identified higher mortality for younger patients in low- and middle-income countries. Thus, timely access to quality emergency care with relatively simple interventions may significantly reduce morbidity and mortality for younger subsets of patients..$^{9,70-73}$ For example, implementing Emergency Triage And Treatment (ETAT) guidelines may improve pediatric care. At a hospital in Malawi, ETAT was responsible for halving mortality rate for pediatric inpatients. ${ }^{73-75}$ This system has already been used in select referral hospitals and primary health centers in Guatemala to successfully train health providers in acute pediatric care, and could be implemented at other rural health centers across the country, including the Hospital Parroquial de San Lucas Tolimán. ${ }^{46,76}$

Respiratory infections remain a top global cause of morbidity and mortality. ${ }^{63}$ Our study corroborated this finding, with $40.4 \%$ of all medical complaints to the ED attributable to respiratory illness. This is particularly concerning in the era of COVID-19. Although COVID-19 patients are unlikely to have co-existent viral and bacterial respiratory infections, there may be significant overlap in patient presentation and comorbidities. ${ }^{77}$ A surge in patients needing diagnosis and treatment of respiratory illness may overwhelm already overburdened health systems, and result in delays in diagnosis and treatment of respiratory cases requiring timely intervention, such as tuberculosis, which remains a major burden of infectious disease in Guatemala. ${ }^{78-80}$ There is evidence that there may be dual risk posed by co-infection with tuberculosis and COVID-19, advancing disease severity and progression for both diseases, and leading to dramatic differences in health services utilization that can affect tuberculosis disease management. ${ }^{81-84}$ It is difficult to quantify the true impact of COVID-19 on this particular hospital and emergency department at this time; however, given the aforementioned issues, it is unlikely that hospital functions will remain unaffected by this evolving pandemic. Indeed, excess mortality due to the pandemic has been documented in Guatemala on a nation-wide level. ${ }^{85}$

Traumatic complaints made up 43.2\% of all surgical presentations to the ED. Notably, $51.99 \%$ of all females presenting with a surgical complaint were classified as having a traumatic injury. Only $39.97 \%$ of males presenting with a surgical complaint, on the other hand, were classified as having a traumatic injury. This is in contrast to a body of existing literature that demonstrates males are generally more likely than females to present to emergency departments for traumatic injury. ${ }^{86-95}$ Detailed etiologies of traumatic surgical complaints were not available in hospital records; however, understanding the nature of trauma may represent a potential future area of study, and an important point of intervention for female patients presenting to the ED with trauma. While we are unable to conclude what is causing the observed phenomena in our study population, we are concerned that previous studies have demonstrated that women may suffer a greater proportion of sexual violence and assault injuries compared to male counterparts. ${ }^{93,96}$ Domestic violence against women is well documented in Guatemala, and may be one factor that has contributed to the trend observed in our study. ${ }^{97-99}$ Future research should explore this potential in a culturally sensitive manner.

Furthermore, the substantial burden of traumatic surgical complaints that were identified on presentation to this ED, and the higher percentage of those referred to another institution compared to admitted to the hospital may underscore the need for improved organization and planning for trauma care services regardless of genderbased differences. Low cost initiatives to streamline trauma care have been evaluated in Mexico, and include the design of specific trauma registries, uniform training for hospital staff involved in the management of trauma cases, and strengthening prehospital services, among others. ${ }^{100-102}$ Similar low-cost efforts could be developed in this setting depending on local interest and resources. For example, an effective prehospital emergency trauma care curriculum was recently developed for lay first responders in the departments of Chimaltenango, Escuintla and Sacatepéquez, and could be modified for use in the San Lucas Tolimán setting. ${ }^{44}$ Long-term capacity building could also include more in-depth analyses of the types of surgical traumas presenting to the $\mathrm{ED}$, and staff concerns regarding the hospital's ability to manage these cases on-site. Identifying any deficits that exist at this hospital could suggest site-specific interventions.

\section{Limitations}

Our descriptive epidemiologic study may have been subject to a few different sources of bias, limiting the interpretation of our results. First, there may be crosslevel confounding by individual level covariates, including individual income. ${ }^{103}$ Presentation to the ED may have been influenced by socioeconomic status and/or educational attainment, leading to significant selection bias. More financially stable individuals, with easy access to transportation, may choose to seek care at larger urban centers rather than at a local rural hospital. Given that a higher proportion of indigenous individuals are socioeconomically disadvantaged, this could have led to an overrepresentation of the indigenous population at Hospital Parroquial de San Lucas Tolimán, and not accurately reflected emergency department usage in non-indigenous populations. For this reason, patient outcome may also be somewhat misleading. Individuals may choose to recover at home given the high cost of referred medical care and hospitalization, despite advice to seek additional treatment. Thus, socioeconomic status could be a confounding variable not readily apparent based on the information contained in this dataset.

Migration across groups may also be a problem. ${ }^{103,104}$ In Guatemala, seasonal labor on agricultural plantations (fincas), including coffee and sugarcane plantations, is a primary source of employment for many individuals. ${ }^{105,106}$ The availability of temporary labor on plantations may cause substantial migration into, and out of, our study population based on season. There may be differences in health risks for temporary workers on plantations compared to permanent residents, given extant labor conditions. ${ }^{106,107}$ For example, labor exploitation and abuses that occur on Guatemalan coffee farms include child labor, the utilization of dangerous forms of transportation, exposure to pesticides/chemicals without adequate personal protective equipment, food and shelter deprivation, and poor living conditions. ${ }^{107}$ This in turn may lead to an increase in ED encounters among groups of seasonal laborers. We may therefore have observed an overrepresentation of laborers whose primary residence is not San Lucas Tolimán or the immediate surrounding rural area.

Finally, non-differential misclassification/measurement error may be a problem. ${ }^{108,109}$ Although hospital staff coded presenting complaint according to a specified system, individuals may have been misclassified if there were multiple presenting complaints or an ambiguous presenting complaint, or if untrained hospital staff filled out the electronic medical record. While we do not expect that this was a significant source of error in this study, in many ecological studies, this type of mis- 
classification can bias results away from null hypotheses. ${ }^{109}$

\section{Conclusions}

Despite limitations, this study generates epidemiologic data that will contribute to the understanding of acute care disease burden and emergency care needs and capacity in a middle-income country, with specific focus on an underserved indigenous population. This information adds to general knowledge of emergency care in this region, and may be used to inform local policy decisions, identify research priorities, create training topics for local health care providers, and perhaps introduce new protocols at rural ED's in Guatemala.

\section{References}

1. Coyle RM, Harrison HL. Emergency care capacity in Freetown, Sierra Leone: a service evaluation. BMC Emerg Med 2015;15:2.

2. Burke TF, Hines R, Ahn R, et al. Emergency and urgent care capacity in a resource-limited setting: an assessment of health facilities in western Kenya. BMJ Open 2014;4:e006132.

3. Hsia R, Razzak J, Tsai AC, Hirshon JM. Placing emergency care on the global agenda. Ann Emerg Med 2010;56:142-9.

4. Shanahan T, Risko N, Razzak J, Bhutta Z. Aligning emergency care with global health priorities. Int J Emerg Med 2018;11:52.

5. Fortuna RJ, Robbins BW, Mani N, Halterman JS. Dependence on emergency care among young adults in the United States. J Gen Intern Med 2010;25:663-9.

6. Howard MS, Davis BA, Anderson C, et al. Patients' perspective on choosing the emergency department for nonurgent medical care: a qualitative study exploring one reason for overcrowding. J Emerg Nurs 2005;31:429-35.

7. Kobusingye OC, Hyder AA, Bishai D, et al. Emergency medical services. In: Jamison DT, Breman JG, Measham AR, et al., eds. Disease control priorities in developing countries. 2nd ed. World Bank; 2006.

8. Smith J, Haile-Mariam T. Priorities in global emergency medicine development. Emerg Med Clin North Am 2005;23:11-29.

9. Obermeyer Z, Abujaber S, Makar M, et al. Emergency care in 59 low- and middle-income countries: a systematic review. Bull World Health Organ 2015;93:577-586G

10. Razzak JA, Hyder AA, Akhtar T, et al. Assessing emergency medical care in low income countries: a pilot study from Pakistan. BMC Emerg Med 2008;8:8.

11. Johnson T, Gaus D, Herrera D. Emergency Department of a Rural Hospital in Ecuador. West $\mathrm{J}$ Emerg Med 2016;17:66-72.

12. Hess A, Thomas T, Contreras R, Green GB. Development of emergency medical services in Guatemala. Prehospital Emerg Care 2004;8:308-12.

13. Baker T, Lugazia E, Eriksen J, et al. Emergency and critical care services in Tanzania: a survey of ten hospitals. BMC Health Serv Res 2013;13:140.

14. Reynolds TA, Mfinanga JA, Sawe HR, et al. Emergency care capacity in Africa: A clinical and educational initiative in Tanzania. J Public Health Pol 2012;33:S126-37.

15. Duke T, Cheema B. Paediatric emergency and acute care in resource poor settings. J Paediatr Child Health 2016;52:221-6.

16. Gosselin RA, Spiegel DA, Coughlin R, Zirkle LG. Injuries: the neglected burden in developing countries. Bull World Health Organ 2009;87:246.

17. Levine AC, Presser DZ, Rosborough S, et al. Understanding barriers to emergency care in low-income countries: view from the front line. Prehosp Disaster Med 2007;22:467-70.

18. Cheng AC, West TE, Limmathurotsakul D, Peacock SJ. Strategies to reduce mortality from bacterial sepsis in adults in developing countries. PLOS Med 2008;5:e175.

19. Kouo-Ngamby M, Dissak-Delon FN, Feldhaus I, Juillard C, Stevens KA, Ekeke-Monono M. A cross-sectional survey of emergency and essential surgical care capacity among hospitals with high trauma burden in a Central African country. BMC Health Serv Res 2015;15:478.

20. Japiong KB, Asiamah G, Owusu-Dabo E, et al. Availability of resources for emergency care at a second-level hospital in Ghana: A mixed methods assessment. Afr J Emerg Med 2016;6:30-7.

21. Anthony DR. Promoting emergency medical care systems in the developing world: weighing the costs. Glob Public Health 2011;6:906-13.

22. Mowafi H, Ngaruiya C, O'Reilly G, et al. Emergency care surveillance and emergency care registries in lowincome and middle-income countries: conceptual challenges and future directions for research. BMJ Glob Health 2019;4:e001442.

23. Holliman CJ, VanRooyen MJ, Green $\mathrm{GB}$, et al. Planning Recommendations for International Emergency Medicine and Out-of-hospital Care System Development. Acad Emerg Med 2000;7:911-7.

24. Alagappan K, Schafermeyer R, Holliman CJ, et al. International emergency medicine and the role for academic emergency medicine. Acad Emerg Med 2007;14:451-6.

25. Reynolds TA, Bisanzo M, Dworkis D, et al. Research priorities for data collection and management within global acute and emergency care systems. Acad Emerg Med 2013;20:1246-50.

26. Paniagua-Avila MA, Messenger E, Nelson CA, et al. The Guatemala-Penn Partners: an innovative inter-institutional model for scientific capacitybuilding, healthcare education, and public health. Front Public Health 2017;5:70.

27. Universidad de San Carlos de Guatemala, Guatemala City, Guatemala. RoshReview.com. Accessed December 5, 2020. Available from: https://www.roshreview. com/global-foundation/profile/universidad-de-san-carlos-de-guatemalaguatemala-city-guatemala/

28. Chary A, Flood D, Austad K, et al. Accompanying indigenous Maya patients with complex medical needs: A patient navigation system in rural Guatemala. Healthc (Amst) 2018;6:144-9.

29. Browne AJ, Smye VL, Rodney P, et al. Access to primary care from the perspective of aboriginal patients at an urban emergency department. Qual Health Res 2011;21:333-48.

30. Thomas DP, Anderson IP. Use of emergency departments by Aboriginal and Torres Strait Islander people. Emerg Med Australasia 2006;18:68-76.

31. Arnaert A, Schaack G. Cultural awareness of Inuit patients' experiences with emergency nursing care. Accident Emerg Nursing 2006;14:97-103.

32. Dell EM, Firestone M, Smylie J, Vaillancourt S. Cultural safety and providing care to aboriginal patients in the emergency department. Can J Emerg Med 2016;18:301-5.

33. Berg K, McLane P, Eshkakogan N, et al. Perspectives on Indigenous cultural competency and safety in Canadian hospital emergency departments: A scoping review. Int Emerg Nursing 2019;43:133-40. 
34. Johnston $\square$ Leek M, Sprivulis P, Stella J, Palmer D. Emergency department triage of indigenous and non-indigenous patients in tropical Australia. Emerg Med 2001;13:333-7.

35. Green T, Green H, Scandlyn J, Kestler A. Perceptions of short-term medical volunteer work: a qualitative study in Guatemala. Global Health 2009;5:4.

36. Berry NS. Who's Judging the Quality of Care? Indigenous Maya and the Problem of "Not Being Attended." Med Anthropol 2008;27:164-89.

37. Cerón A, Ruano AL, Sánchez S, et al. Abuse and discrimination towards indigenous people in public health care facilities: experiences from rural Guatemala. Int $J$ Equity Health 2016;15:77.

38. Ruano AL, Sánchez S, Jerez FJ, Flores W. Making the post-MDG global health goals relevant for highly inequitable societies: findings from a consultation with marginalized populations in Guatemala. Int J Equity Health 2014;13:57.

39. Lindblade KA, Johnson AJ, Arvelo W, et al. Low usage of government healthcare facilities for acute respiratory infections in guatemala: implications for influenza surveillance. BMC Public Health 2011;11:885.

40. Van Der Stuyft P, Delgado E, Sorensen SC. Utilisation rates and expenditure for public and private, curative-care services in semi-urban Guatemala. Ann Tropical Med Parasitol 1997;91:20916.

41. Berry NS. Kaqchikel midwives, home births, and emergency obstetric referrals in Guatemala: Contextualizing the choice to stay at home. Soc Sci Med 2006;62:1958-69.

42. Becker S, Fonseca-Becker F, SchenckYglesias C. Husbands' and wives' reports of women's decision-making power in Western Guatemala and their effects on preventive health behaviors. Soc Sci Med 2006;62:2313-26.

43. Rööst M, Johnsdotter S, Liljestrand J, Essén B. A qualitative study of conceptions and attitudes regarding maternal mortality among traditional birth attendants in rural Guatemala. BJOG 2004;111:1372-7.

44. Delaney PG, Figueroa JA, Eisner ZJ, et al. Designing and implementing a practical prehospital emergency trauma care curriculum for lay first responders in Guatemala. Trauma Surg Acute Care Open 2020;5:e000409.

45. Walker DM, Holme F, Zelek ST, et al. A process evaluation of PRONTO simulation training for obstetric and neonatal emergency response teams in Guatemala. BMC Med Educ 2015;15:117.

46. Crouse HL, Torres F, Vaides H, et al. Impact of an Emergency Triage Assessment and Treatment (ETAT)based triage process in the paediatric emergency department of a Guatemalan public hospital. Paed Int Child Health 2016;36:219-24.

47. Bose S, Bream K, Barg F, Band R. Willingness to pay for emergency referral transport in a developing setting: a geographically randomized study. Acad Emerg Med 2012;19:793800.

48. Evanson TA, Zust BL. The meaning of participation in an international service experience among baccalaureate nursing students. Int $\mathrm{J}$ Nurs Educ Scholarship 2004;1:1070

49. Andrews CM, Wyne K, Svenson JE. The use of traditional and complementary medicine for diabetes in rural Guatemala. J Health Care Poor Underserved 2018;29:1188-208.

50. Chickering WH. A guide for visiting clinicians to Guatemala: common presenting symptoms and treatment. J Transcult Nurs 2006;17:190-7.

51. Chamarbagwala R, Morán HE. The human capital consequences of civil war: Evidence from Guatemala. J Devel Econ 2011;94:41-61.

52. Svenson EL, Tun R, Conway JH, et al. A one health approach to compare selfprescribed antibiotic use across rural and semi-urban populations in San Lucas Tolimán, Guatemala. J Health Care Poor Underserved 2021;32:1798817.

53. Sperling J. The influence of poverty and violence on the therapeutic landscapes of the Kaqchikel. Published online 2006. Accessed December 26, 2021. Available from: https://uwspace.uwaterloo.ca/handle/1 0012/982

54. Ao T, McCracken JP, Lopez MR, et al. Hospitalization and death among patients with influenza, Guatemala, 2008-2012. BMC Public Health 2019;19:463.

55. Gragnolati M, Marini A. Health and poverty in Guatemala. Soc Sci Res Network 2003. Accessed December 22, 2021. Available from: https://papers.ssrn.com/abstract $=6363$ 28

56. Bowser DM, Mahal A. Guatemala: The economic burden of illness and health system implications. Health Policy 2011;100:159-66.

57. Becerril-Montekio V. Sistema de salud de Guatemala. Salud Pública de México 2011;53:12.

58. Peltan ID. Disaster relief and recovery after a landslide at a small, rural hospital in Guatemala. Prehosp Disaster Med 2009;24:542-8.

59. Duffy S, Norton D, Kelly M, et al. Using community health workers and a smartphone application to improve diabetes control in rural Guatemala. Glob Health Sci Pract 2020;8:699-720.

60. Inicio. HOSPITAL GREGORIO SCHAFFER. Accessed December 22, 2021. http://hospitalgregorioschaffer.org/

61. Healthcare - Friends of San Lucas. Accessed December 26, 2021. https://sanlucasmission.org/programs/healthcare/

62. López-Carr D, Davis J, Jankowska MM, et al. Space versus place in complex human-natural systems: Spatial and multi-level models of tropical land use and cover change (LUCC) in Guatemala. Ecological Modelling 2012;229:64-75.

63. Chang CY, Abujaber S, Reynolds TA, et al. Burden of emergency conditions and emergency care utilization: New estimates from 40 countries. Emerg Med J 2016;33:794-800.

64. Mowafi H, Dworkis D, Bisanzo M, et al. Making recording and analysis of chief complaint a priority for global emergency care research in lowincome countries. Acad Emerg Med 2013;20:1241-5.

65. Kironji AG, Hodkinson P, de Ramirez $\mathrm{SS}$, et al. Identifying barriers for out of hospital emergency care in low and low-middle income countries: a systematic review. BMC Health Serv Res 2018;18:291.

66. Tiwari Y, Goel S, Singh A. Arrival time pattern and waiting time distribution of patients in the emergency outpatient department of a tertiary level health care institution of North India. J Emerg Trauma Shock 2014;7:160-5.

67. Wesson HKH, Stevens KA, Bachani AM, et al. Trauma systems in Kenya: A qualitative analysis at the district level. Qualitative Health Research 2015;25: 589-99.

68. Chomat AM, Kring B, Bekker LP. Approaching maternal health from a decolonized, systemic, and culturally safe approach: case study of the Mayan-indigenous populations of Guatemala. In: Schwartz DA, ed. Maternal death and pregnancy-related morbidity among indigenous women of Mexico and Central America: An anthropological, epidemiological, and biomedical approach. Global Maternal 
and Child Health. Springer International Publishing; 2018:483511.

69. Lindstrom DP, Muñoz-Franco E. Migration and maternal health services utilization in rural Guatemala. Soc Sci Med 2006;63:706-21.

70. Razzak J, Usmani MF, Bhutta ZA. Global, regional and national burden of emergency medical diseases using specific emergency disease indicators: analysis of the 2015 Global Burden of Disease Study. BMJ Global Health 2019;4:e000733.

71. Salomon JA, Wang H, Freeman MK, et al. Healthy life expectancy for 187 countries, 1990-2010: a systematic analysis for the Global Burden Disease Study 2010. Lancet 2012;380:2144-62.

72. Viner RM, Coffey C, Mathers C, et al. 50-year mortality trends in children and young people: a study of 50 lowincome, middle-income, and highincome countries. Lancet 2011;377:1162-74.

73. Baker T. Pediatric emergency and critical care in low-income countries. Pediatric Anesthesia 2009;19:23-7.

74. Molyneux E, Ahmad S, Robertson A. Improved triage and emergency care for children reduces inpatient mortality in a resource-constrained setting. Bull World Health Organ. 2006;84:314-9.

75. Brugnolaro V, Fovino LN, Calgaro S, et al. Pediatric emergency care in a low-income country: Characteristics and outcomes of presentations to a tertiary-care emergency department in Mozambique. PLOS One 2020;15:e0241209.

76. Kapoor R, Sandoval MA, Avendaño L, et al. Regional scale-up of an Emergency Triage Assessment and Treatment (ETAT) training programme from a referral hospital to primary care health centres in Guatemala. Emerg Med J 2016;33:611-7.

77. Shah SJ, Barish PN, Prasad PA, et al. Clinical features, diagnostics, and outcomes of patients presenting with acute respiratory illness: A retrospective cohort study of patients with and without COVID-19. EClinicalMedicine 2020;27:100518.

78. Ikeda JM, López Tellez CA, Hudes ES, et al. Impact of Integrating HIV and TB Care and Treatment in a Regional Tuberculosis Hospital in Rural Guatemala. AIDS Behav 2014;18:96103.

79. Hogan AB, Jewell BL, Sherrard-Smith E, et al. Potential impact of the COVID-19 pandemic on HIV, tuberculosis, and malaria in low-income and middle-income countries: a modelling study. Lancet Global Health 2020;8:e1132-41.

80. Lloyd-Sherlock P, Ebrahim S, Geffen L, McKee M. Bearing the brunt of covid-19: older people in low and middle income countries. BMJ 2020;368:m1052.

81. Visca D, Ong CWM, Tiberi S, et al. Tuberculosis and COVID-19 interaction: A review of biological, clinical and public health effects. Pulmonology 2021;27:151-65.

82. Yasri S, Wiwanitkit V. Tuberculosis and novel Wuhan coronavirus infection: Pathological interrelationship. Indian J Tuberc 2020;67:264.

83. Migliori GB, Thong PM, Akkerman O, et al. Worldwide Effects of Coronavirus Disease Pandemic on Tuberculosis Services, January-April 2020. Emerging Infect Dis 2020;26:203163

84. Nachega JB, Kapata N, Sam-Agudu NA, et al. Minimizing the impact of the triple burden of COVID-19, tuberculosis and HIV on health services in subSaharan Africa. Int $\mathrm{J}$ Infect Dis 2021;113:S16-S21.

85. Martinez-Folgar K, Alburez-Gutierrez D, Paniagua-Avila A, et al. Excess mortality during the COVID-19 pandemic in Guatemala. Am J Public Health 2021;111:1839-46.

86. Mehmood A, Razzak JA, Kabir S, et al. Development and pilot implementation of a locally developed Trauma Registry: lessons learnt in a lowincome country. BMC Emerg Med 2013;13:4

87. Casey ER, Muro F, Thielman NM, et al. Analysis of traumatic injuries presenting to a referral hospital emergency department in Moshi, Tanzania. Int J Emerg Med 2012;5:28.

88. Ladha KS, Young JH, Ng DK, et al. Factors Affecting the Likelihood of Presentation to the Emergency Department of Trauma Patients After Discharge. Ann Emerg Med 2011;58:431-437.

89. Gaw CE, Zonfrillo MR. Emergency department visits for head trauma in the United States. BMC Emerg Med 2016;16:5.

90. Clark K, Rao A, Chen V, et al. We need to target trauma: A prospective observational study in Eastern Cape Province, South Africa. SAMJ 2020;110:38-43.

91. Blom L, Klingberg A, Laflamme L, et al. Gender differences in burns: A study from emergency centres in the Western Cape, South Africa. Burns
2016;42:1600-8.

92. Hode L, Madougou S, Fatigba HO, et al. The direct cost of treatment of traumatic brain injury in a Sub-Saharan African country (Benin). World Neurosurg 2017;99:210-3.

93. Sanyang E, Peek-Asa C, Bass P, et al. Injury factors associated with discharge status from emergency room at two major trauma hospitals in The Gambia, Africa. Injury 2017;48:14518.

94. Maegele M, Lefering R, Sakowitz O, et al. The Incidence and Management of Moderate to Severe Head Injury. Dtsch Arztebl Int 2019;116:167-73.

95. Arslan ED, Solakoglu AG, Komut E, et al. Assessment of maxillofacial trauma in emergency department. World J Emerg Surg 2014;9:13.

96. Tennakoon L, Hakes NA, Knowlton LM, Spain DA. Traumatic Injuries Due to Interpersonal and Domestic Violence in the United States. J Surg Res 2020;254:206-16.

97. Johri M, Morales RE, Boivin JF, et al. Increased risk of miscarriage among women experiencing physical or sexual intimate partner violence during pregnancy in Guatemala City, Guatemala: cross-sectional study. BMC Pregnancy Childbirth 2011;11:49.

98. Ogrodnik C, Borzutzky S. Women under attack: violence and poverty in Guatemala. J Int Women's Studies 2011;12.

99. Halvorsen R. Women caught in a culture of violence in Guatemala. Nurs Women's Health 2014;18:425-8.

100. Arreola-Risa C, Mock C, Vega Rivera $\mathrm{F}$, et al. Evaluating trauma care capabilities in Mexico with the World Health Organization's Guidelines for Essential Trauma Care publication. Rev Panam Salud Publica 2006;19:94103.

101. Mock C, Joshipura M, Quansah R, Arreola-Risa C. Advancing injury prevention and trauma care in North America and globally. Surg Clin North Am 2007;87:1-19.

102. Arreola-Risa C, Vargas J, Contreras I, Mock C. Effect of emergency medical technician certification for all prehospital personnel in a Latin American city. J Trauma 2007;63:914-9.

103. Morgenstern H. Ecologic Studies in Epidemiology: Concepts, Principles, and Methods. Ann Review Public Health 1995;16:61-81.

104. Tong S. Migration bias in ecologic studies. Eur J Epidemiol 2000;16:3659. 
105. Fischer EF, Victor B. High-end coffee and smallholding growers in Guatemala. Latin Am Res Rev 2014;49:155-77.

106. Butler-Dawson J, Krisher L, Asensio $\mathrm{C}$, et al. Risk Factors for Declines in Kidney Function in Sugarcane Workers in Guatemala. J Occup Environ Med 2018;60:548-58.

107. Verité, United States Department of
Labor. Research on indicators of forced labor in the supply chain of coffee in Guatemala. United States Department of Labor. Accessed December 10, 2020. https://www.verite.org/wp-content/uploads/2016/11/Research-onIndicators-of-Forced-Labor-in-theGuatemala-Coffee-Sector_ 9.16.pdf

108. Greenland S, Brenner H. Correcting for non-differential misclassification in ecologic analyses. J Royal Statistical Soc Series C (Applied Statistics) 1993;42:117-26.

109. Guthrie KA, Sheppard L. Overcoming biases and misconceptions in ecological studies. J Royal Statistical Society: Series A (Statistics in Society) 2001;164:141-54. 